\title{
Avrupa Seramik Sanatında Endüstrileşme Süreci ve Cumhuriyet Sonrası Türk Seramik Sanatına Yansımaları
}

\author{
Öğr. Gör. Dr. Naile Salman Çevik
}

\section{Öz}

Sanat, toplum ve kültür birbiri içinde eriyen, hatta zaman içinde evrimleşen bir biçim olarak karşımıza çıkmaktadır. Toplumsal yaşam döngüsünün kültürel yapı üzerindeki etkilerinin veya etkilemelerinin en önemli değerlerinden birisi de tartışmasız olarak Endüstri Devrimi'dir.

Endüstri Devrimi'nin toplumsal ve kültürel yansımalarının bir sonucu/başlangıcı olarak bilim ve sanat alanında farklılaşan ilkeler çerçevesinde şekillenen yeni düşünce sistemi sayesinde seramik sanatında, endüstrisinde ve eğitiminde çağdaş bir anlayış benimsenmiştir. Bu ekonomik, sosyal ve kültürel süreç kapsamında Çağdaş Seramik Sanatı, Arts and Crafts Hareketi ve Bauhaus Ekolü'nden etkilenmişlerdir. Bu süreçler seramik sanatının gelişiminin ötesinde seramik sanatının, eğitiminin ve endüstrisinin gelişmesinde de önemli rol oynamıştır.

Anahtar Kelimeler: Seramik Sanatı, Endüstri Devrimi, Türk Seramik Sanatı

\section{INDUSTRIALIZATION PROCESS IN EUROPEAN CERAMIC ART AND ITS REFLECTIONS ON POST-REPUBLIC TURKISH CERAMIC ART}

\begin{abstract}
Art, society and culture appear as a form which melts by getting inter-transcendental, even evolving in time. One of the most important paradigm of the effects or influences of social life cycle on cultural structure is inarguably the Industrial Revolution.

As a result, start of social and cultural reflections of the Industrial Revolution, thanks to a new thought system that is shaped in frame of differentiating principles in science and art fields, a contemporary sense has been adopted in art, industry and education of ceramic. In these cope of this economic, social and cultural process, the Contemporary Ceramic Art gathered speed by means of talented Pioneer artists such as ismail Hakkı Oygar, Vedat $\mathrm{Ar}$ and Hakkı lizzet. These figures, which were sent abroad to have art education, were influenced by Arts and Crafts Movement and Bauhaus Ecole in that period. These processes not only played a great role in development of ceramic art, but also in development of ceramic education and industry as well.
\end{abstract}

Keywords: Ceramic Art, Industrial Revolution, Turkish Ceramic Art

Öğr. Gör. Dr. Naile Salman Çevik,. Gazi Üniversitesi, Güzel Sanatlar Fakültesi,

Heykel Bölümü. Ankara. E-posta: nailesalman@gmail.com 


\section{Yenilenme Süreci}

Dinamik ve devingen bir durum içinde yer alan toplum kavramı, içinde yaşayan bireylerin arasında dolaşan fikirler aracılığıyla farklı coğrafyalarda ve farklı insanlar arasında yeniden oluşmaktadır. 18. yüzyılda İngiltere'de sosyal, kültürel ve ekonomik yapıdaki köklü değişiklikler Sanayi Devrimi'nin burada filizlenmesine neden olmuştur. Bu dönemde bilim adamlarının ve mühendislerin yaptıkları yeni buluşlar sanayi alanlarının genişlemesine, enerji ve hammadde kaynaklarının endüstriyel alanda yaygın olarak kullanılmasına geniş imkanlar sağlamıştır (Bektaş, 1992:14-16; Özturanlı, 1989:40-44; Soner, 2007: 2-12).

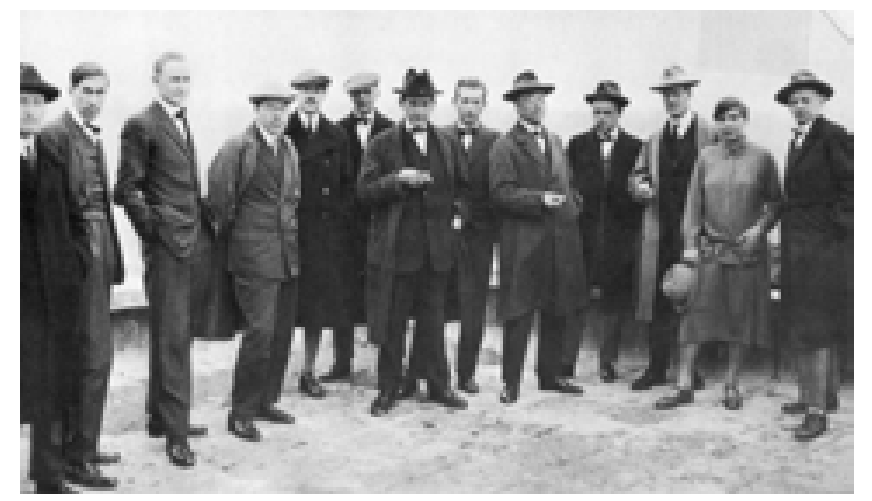

Fotoğraf I: Bauhaus Üstatları Dessau'da Bauhaus Binasııın Çatısında

Doğadan esinlenilmiş yaratıcı, özgür formlar için tarihi modeller terk edilmiş, Art Nouveau, yüzyıl sonu ve 20. yüzyıl başında mimaride ve dekoratif sanatlardaki yeni ifadeyi tanımlayanbir isme dönüşmüştü. Modern dönemin başlangıcını ifade eden bu sanat, Fransa'da "Art Nouveau", "Fin de Siècle Stili", Almanya'da "Jugendstil", Avusturya'da "Viyana Secession", Ingiltere'de "New Art", "Liberty", Türkiye'de "1900'lerin Sanatı", "Yeni Sanat" olarak adlandııımıştır (Yıldıım, 2011: 119-120; Howard, 1996: 74).

Endüstrileşmeyle birlikte, giderek insan duyarlığından ve sıcaklığından uzak, kalıplaşmış, birbirinin taklidi, soğuk nesnelerin yaşama girmeye başladığının ayrımına varılınca, John Ruskin ve William Morris'in İngiltere'de 1897 yılında kişisel çabalarıyla endüstri ürünlerine sanatsal içerik katma düşüncesi doğmuştur. Endüstri ile sanat arasındaki uçurumu 
kapatmak amacıyla 1919'da Walter Gropius tarafından kurulan Bauhaus, dönemin ünlü sanatçılarını çatısı altına toplamıştı (Gençaydın, 1997: iii). Bauhaus fikirlerinin, kavramlarının ve pedagojik yaklaşımlarının dünyanın pek çok farklı yerine yapmış olduğu "yolculuk" Bauhaus düşüncesinin beslenmesine yardımcı olmuştur (Yorgancıoğlu, 2009: 153).

Bauhaus düşüncesinin asıl gücü, sistematik bir eğitim anlayışına dönüşmüş olmasından kaynaklanmaktadır (Yorgancıoğlu, 2009: 154). Gropius'un Bauhaus okulunu kurma öngörüsü ve anlayışı, daha sonraları tekniği ve sanatsal özgürlüğü içinde barındıran tasarımın ortaya çıkmasına neden olmuştur. Gropius'un tarzı ile formlardaki Bauhaus dili yalın bir zarafeti yansıtır (Yağcı, 2009: 17).

Güzel ve faydalı kavramlarının bütünlüğünden kalkan bu yeni estetik, özellikle ergonominin ve endüstri tasarımının kuruluşu ile sanatı müze ve galerilerin tutsaklığından kurtarıp, insanın günlük yaşamına, insanın oturduğu kentin sokaklarına ve evinin içine sokmuştur (Tunalı, 1997: 76). Hiç şüphesiz Bauhaus, ekolünün sınırları içinde kurulduğu ülkenin sınırlarını çoktan aşarak birçok ülkeyi etkisi altına almıştı.

Türk sanatının görsel dilinin çeşitlenmesinde de politik çevrelerin yanı sıra sanatçılarının ve aydınlarının biçimsel ve içeriksel yenilenmelerde Bauhaus ekolünden etkilendikleri gözlenmektedir. Sanat ve eğitimi açısından bakıldığı zaman akademik alanlardaki atılımlar dönemsel olarak Cumhuriyetin ilanına rastlamaktadır.

Bu anlamda, Bauhaus ekolü Türkiye'de 20. yüzyılın başında öncelikle pedagojik, kültürel ve endüstriyel çevrelerde yeni yaşam biçimlerine yeni anlamlar kazandırılmasında lokomotif niteliği sağlayan bir yapıdır. $\mathrm{Bu}$ anlamda günümüzde eğitimi yönlendiren temel eğitim ilkelerinin ve sürdürülebilir üretim süreçlerinin içinde de Bauhaus'un izlerini görebilmek mümkündür (Bakla, 2010: 48).

Cumhuriyet'in ilanından sonra, Cumhuriyet ideolojisinin bir yansıması olarak tanımlayabileceğimiz, sanat ile zanaatın ilişkisini güçlendirecek bir eğitim kurumu olan Ankara Gazi Eğitim Enstitüsü Resim-İ̧ Bölümü kurulur. 1932'de açılan bölümün temel amacı iki eksende ilerler. Ilki, Akademi'nin gerçekleştirmekte İstanbul'la sınırlı kaldığı "çağdaşlaşma" 
hareketini eğitimciler aracılığıyla Anadolu'ya götürmek, diğeri ise sanatı zanaatla birleştirerek sanatın toplumsal amacını yeniden keşfetmektir. Okulun misyonlarından ikincisinin, Almanya'da 1919'da Weimar Güzel Sanatlar Okulu'nu birleştiren Walter Gropius tarafından kurulan Bauhaus'un amaçlarıyla da çakışıyor olması tesadüf değildir. İsmail Hakkı Baltacıoğlu'nun önerisiyle Almanya ve Avusturya'ya gönderilen İsmail Hakkı Tonguç, Malik Aksel, Şinasi Barutçu, Hayrullah Örs ve Sait Yada gibi isimler, Alman eğitim sistemini yerinde görür ve ülkeye dönerler (Aliçavuşoğlu, 2009: 23).

Bu dönemde üniversitelerin sanatla ilgili bölümlerinde; alanlar arası ders seçme olanağının tanınması, öğrencilere seramiği tanıma şansını vermiştir. Yaratıcı ve bireysel kimliklerini geliştirmeleri için olanakların çoğaltılmış olması sanatın sadece tek bir malzemeyle sınırlandırılmamasını ve bir bütün olarak algılanmasını sağlamıştır. Bu düşünceler, Bosworth (2006)'un bu konudaki yazısıyla desteklenir; "Sanatta; kullanılan malzemeden daha çok kavram ön plana çıkmış, sanatçı kullandığı malzemeyi sorgulamaya ve yeniden değerlendirmeye başlamış, üniversitelerdeki sanat bölümlerinde ve meslek yüksekokullarında çanak-çömlek terimi yerine seramik terimi yerleşmeye başlamıştır. Bu kelime değişimi büyük bir ölçüde kilin, pişirimini ve bunların kullanımının keşfini cesaretlendirmiştir. Öğrenciler, yeni teknolojileri ve birlikte kullanılabilir malzemeleri keşfetmeye teşvik edilmiştir. Daha sonraları üniversiteler, sanat okulları ve meslek yüksekokulları birçok alandan oluşan tasarım ve el sanatları kurslarını bölümler arası çalışma seçeneğiyle birlikte öğrencilerine sunmaya başlamışlardır" (Bosworth, 2006: 9).

\section{Dünyada Çağdaş Seramik Sanatının Oluşumu}

Ingiltere'de Endüstri Devrimi'nin gerçekleştirilmesinden sonra, o güne kadar geleneksel anlamda çömlekçi atölyelerinde üretilen seramik, endüstrileşme süreciyle birlikte onun getirmiş olduğu süratli ve ucuz üretim tarzına dönüşmüştür. Böylece ortaya tek düze, yoz, gösterişli, ucuz ürünler çıkmaya başlamıştır. Bu anlamda üretimde seramiğin çağdaş boyutu sadece teknik ve üretim anlamında bir gelişme kaydetmiştir. Endüstrinin tüketim çarkına sıkışan seramik üretimini daha nitelikli hale getirmek ve el sanatı konumundan kurtararak gelişimine yön vermek anlamında ilk tepki, İngiltere'de William Morris'in kişiliğinde kendini 
göstermiştir. "Endüstri Devrimini insanlığın kendine getirdiği en büyük felaket olarak gören Morris, El Sanatları ve Sanat Akımı'nı (Arts and Crafts Movement) başlattı. Amaçları insan emeğine saygı ve maddeye doğru yaklaşımdı (Tansuğ, 1988: 93; Ağatekin, 1993: 20-21; Tansuğ, 1999: 157-158; Turan, 2009: 133-136). El sanatlarının yenileştirilmesi, kaliteli ve zevkli ürünlerin ortaya konması ve el sanatlarına duyarlılığın artırılmasıyla başlayan Arts and Crafts Movement, Çağdaş Seramiğin endüstriyel gelişme içerisinde kendine yeni pazarlar bulmasına, sanat okullarının ve akademilerin açılmasına neden olmuştur (Kura, 1989: 7-8).

Batıda bu anlamda gelişmeye başlayan çizgi, Uzakdoğu seramiklerinin sırlarının çözülmeye başlanmasıyla birlikte daha nitelikli ve teknik yönden zengin ürünlerin yavaş yavaş ortaya çıkmasını sağladı. Uzakdoğu seramiklerinin anlam ve değerini batıya taşıma anlamında bazı sanatçılar öncülük yapmıştır. Bu öncülerden biri de, resim öğretmenliği yapmak için gittiği Japonya'da çömlekçi olmaya karar veren ve sonra İngiltere'ye dönerek, Uzakdoğu seramiklerini batıya taşıyan Bernard Leach'dir. Leach böylece tüm işlemleri kendisi yapan, sır ve form mükemmeliyetini araştıran ve uygulayan çağdaş bir sanatçı niteliğini ortaya çıkarmıştır. 1940 yılında yazdığı "Bir Çömlekçinin Kitabı" seramik literatürünün ilk klasikleri arasına girmiştir (Tansuğ , 1988: 93).

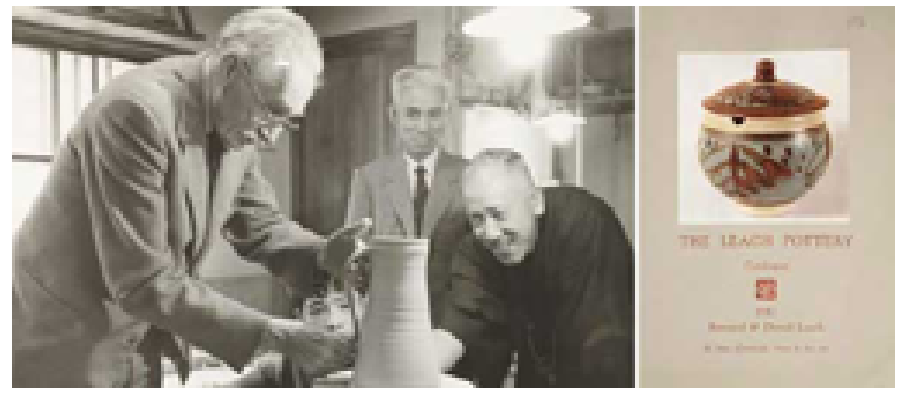

Fotoğraf 2: Bernard Leach Atölyesinde

Batıda 18. yüzyıl sonlarında Arts and Crafts Movement ile başlayan süreç II. Dünya Savaşı sonrası seramik pazarının ve seramiğe verilen ilginin artması, teknolojinin ilerlemesi, seramiğin uluslararası fuarlarda görülmeye başlaması ile resim ve heykelle uğraşan sanatçıların da ilgisini çekmeye başladı. Bu ilgi, seramik malzemenin incelenmesi ve niteliklerinin belirlenmesi yolunda yapılan araştırma ve çalışmaları da beraberinde 
getirdi (Kura, 1989: 8).

Seramiğin kendini "Sanat Seramiği" olarak 20. yüzyıl içerisinde kabul ettirmesi diğer plastik sanat dallarına göre yeni bir disiplin olarak nitelendirilmesinin nedenidir. "Sanat Seramiği" olarak adlandırılan bu çalışmalar, heykel sanatının biçim ve içeriğinin yanında resim sanatının renk öğesini de bünyesinde barındırmaktadır (Sönmez, 2002: 178-179).

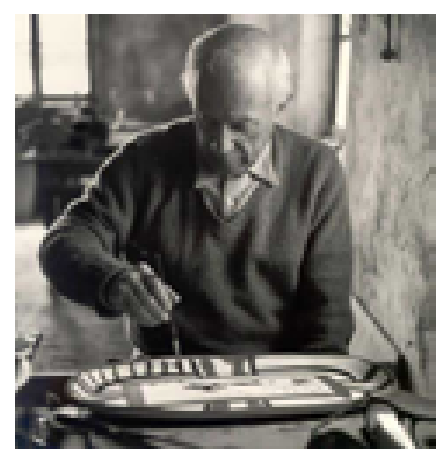

Fotoğraf 3: Picasso Seramik Çalışırken

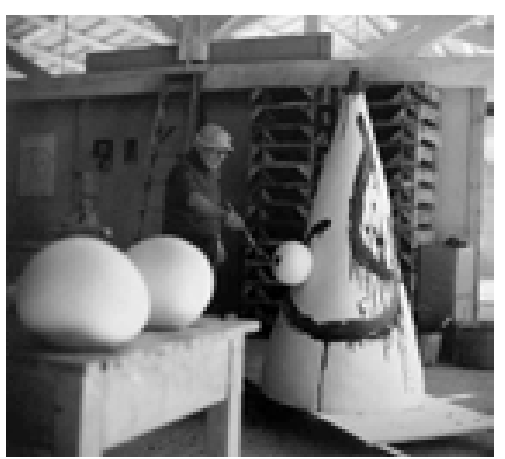

Fotoğraf 4: Miro Seramik Çalışırken

20. yüzyıl sanatçılarından Picasso, Miro, Mattisse, Braque ve Chagall resimlerini seramik bünyeler üzerine taşımışlar ve özgün denemelerde bulunmuşlardır.

Seramik sanatına ivme kazandıran tüm bu gelişmeler Picasso ve Miro'nun seramik yapıtları ile çağdaş anlamdaki boyutuna oturdu. $\mathrm{Bu}$ boyuta gelinmesinde hiç şüphesiz seramiğin teknolojik gelişiminin çözümlenmesinin yapılmış olması önemli bir etkendi.

Avrupa örneği gibi, Türkiye'de de 1957 yılından başlayarak farklı disiplinlerden Bedri Rahmi Eyüboğlu, Mengü Ertel, Mustafa Pilevneli, Cihat Burak, Ali İsmail Türemen gibi bir çok sanatçı sanat yaşamlarının belli dönemlerinde seramik pano ve form üretmişlerdir (Özer, 2012: 5758).

Endüstri devriminin ve bir dizi toplumsal devrimin ardından, 20. yüzyıla girildiğinde sanatın eski dili artık modern insan bilinci için yeterli değildi. İster istemez eski dil kalıpları çatlayacaktı. Sanatların, değişken ve iç 
içe geçen karakterleri dikkate alınmaya başlandı. Yeni arayışların içine giren ressam ve heykeltıraşlar, resim ve heykel sanatının birçok öğesinin yanı sıra, uzaysal boşluğu da sanatsal bir malzeme olarak bünyesinde bulunduran seramik sanatına yöneldiler. Seramiğin sunduğu sınırsız imgelemle seramik eserler üretmeye başladılar. Hacim-imge, hacim-işlev ve imge-işlev ilişkisi araştıııırken, seramikte resim olgusu canlandı. 20. Yüzyıl ressamının gözü, seramiğe yeni yollar açtı, seramiği yeniledi ve Kilin Konukları olarak adlandırılan bu sanatçıların birçoğu seramikle uzun ve sadık bir ilişki içinde oldu. Seramik onların sanatlarına yeni bir boyut kazandırdı (Çil, 2006: 566).

\section{3. Çağdaş Türk Seramik Sanatının Oluşumu}

Klasik anlamda seramik sanatı iki önemli grubu içerir. Bunlardan ilki endüstriyel seramik sanatıdır ve bu özellikle 19. yüzyıldan sonra izlenir. Endüstri devriminin tüm dünyayı sarmaladığı bu dönemde, küçük atölyelerde tek tek üretilmeye çalışılan seramik ürünler ihtiyaca cevap veremez olmuştur ve seri üretim seramik alanında da zorunluluk olmuştur. Endüstriyel Seramik Sanatına bu açıdan bakıldığında hızlı, seri, ucuz maliyetle, iyi kazanç elde edildiği görülmüş ancak bu ucuz, yozlaşmış, çirkin, taklit el sanatları ürünlerinin de ortaya çıkmasına neden olmuştur. Klasik seramik sanatının ikinci grubunu oluşturan ve özgün (soyut, serbest) seramik sanatı olarak tanımlanan sanat, tamamen özgür bir anlatımı yeğlemektedir. Günümüzde artık seramik çamuru bir ham madde, bir malzeme olarak görülüp pek çok yardımcı malzeme ile desteklenerek kendi niteliklerini diğer malzemelerle de paylaşma yolundadır (Özen, 1993: 161; Erzen,1991: 11-12).

\section{1. Ülkemizde Seramik Sanatı Eğitimi}

Bütün el sanatlarında görüldüğü gibi seramik ve çini yapımında da eğitim, usta çırak ilişkisi içinde süregelmiştir. Cumhuriyetin ilk yıllarında, diğer sanat dallarında olduğu gibi seramikte de, eğitim görmek üzere bazı sanatçılar yurtdışına yollanmıştır. Bunlardan İsmail Hakkı Oygar ve Vedat Ar Fransa'da, Hakkı İzzet ise Almanya'da eğitimlerini sürdürmüşler, yurda dönüşlerinde de seramik eğitiminin kurumsallaşmasını sağlamışlardır. Sanayi-i Nefise Mektebi olarak bilinen daha sonra Güzel Sanatlar Akademisi adını alan okulun müdürü, ressam Namık İsmail Bey'in 
girişimleri ile Tezyinat Bölümü'ne bağlı olarak "Seramik ve Türk Çiniciliği Atölyesini" kurma görevini Paris'ten dönen İsmail Hakkı Oygar'a vermiştir (1929). İsmail Hakkı Oygar'ın katkısıyla, seramik eğitiminde örgütlenme, endüstri işbirliği, yurtiçi ve uluslararası seramik sanatı ilişkilerinin temeli atılmıştır. Ülkenin seramik endüstrisinde intiyaç duyulan yetişmiş eleman boşluğunu doldurmak, çağdaş sanat ve endüstri alanında atılımlar yapmak için kurulan Güzel Sanatlar Akademisi Seramik Bölümü'nü, daha sonraki yıllarda Ankara Gazi Terbiye Enstitüsü'ndeki seramik atölyesinin kuruluşu izlemiştir. İstanbul'da 1958 yılında Devlet Tatbiki Güzel Sanatlar Yüksek Okulu'nun kurulması ile seramik eğitimi veren kuruluşların sayısı artmıştır (Anılanmert, 1999: 67).

\section{2. Ülkemizde Seramik Endüstrisi}

İstanbul'da çini üretimi için ilk girişim Nevşehirli Damat İbrahim Paşa tarafından yapıldı. İbrahim Paşa, İznik'ten getirttiği malzeme ve ustalarla, 1660 yılında İstanbul Tekfur Sarayı'nda bir çini atölyesi kurdurttu. 18. yüzyıldan başlayarak, İstanbul'da porselen üretmek için kıpırdanmalar oldu. Galata, Balat, Ayvansaray, Eyüp ve Beykoz' daki dağınık çini ve çömlek imalathanelerinde beyaz pişen, porselene benzer seramikler yapılmaya başlandı (Yılıkoğlu, 2009: 7; Seramik Tanıtım Komitesi, 2003:13-14). Batı tekniğinde porselen üretimi girişimi ilk kez Abdülmecid (18391861) döneminde başlatılmıştır. Bu dönemde Beykoz-Incirli Köyü'nde, 1845 yııında, Tophane Nazırı Fethi Paşa'nın önderliğinde, hammaddesi yurtdışından getirtilen bir seramik fabrikası kurulmuştur (Yılıkoğlu, 2009: 8; Özturanlı, 1998: 32-33; Ağatekin, 1993; Altıparmak, 2002: 35). Tanzimat'ın ilanından sonra, 1894'te II. Abdülhamid tarafından Sevr Fabrikası örnek alınarak kurulan Yıldız Porselen Fabrikası, saray atölyesi niteliğinde, lüks kalitede imalat yapan, devlet ve saraya hizmet eden bir kuruluştur (Küçükerman, 1987). Yıldız Porselen Fabrikası'nın, kil dahil tüm hammaddelerinin dışarıdan getirilmesi, yerli ve yabancı sanatçıların üretimde yer alması ile Fransız sanat anlayışı porselene yansımıştır. Bu dönemde çağın sanat akımı olan barok, rokoko üslupları dönemin porselenlerinde de izlenir (Ağatekin, 1993: 14-15; Anılanmert, 1999: 67).

Türkiye'de seramik endüstrisinin temeli, Cumhuriyet'in ilk yıllarında İzmir'de düzenlenmiş bulunan I. İktisat Kongresi'nde atılmıştır. Sümerbank'ın kurulması ve 1933 yılında İstanbul ve Kütahya'yı kapsayan 
seramik endüstrisi etüt ve projelerinin başlaması günümüz endüstrisinin ilk girişimleridir. Avrupa'da 18. Yüzyılda toplu üretime geçildiği görülmektedir. Zengin süslemeli, Çin ve Barok üsluplarının karısıımı ile yapılmış biblo, tabak, vazo gibi ürünler, yumuşak porselen olarak bilinen bir hamur yapısı ile üretilmiş ve Fransızlar bu akımın öncüleri olmuştur. Daha sonra Fransa'da sarayın desteği ile Sevr Fabrikası kurulmuştur (Turan, 2009: 130-135).

Seramik üretiminin tam anlamıyla endüstrileşmesi 18. yüzyıl 'Endüstri Devrimi' ile olmuştur. Endüstri Devrimi'nin ortaya çıkışıla birlikte seri üretimin gündeme gelmesi seramik endüstrisinin ve tasarım gereksiniminin ortaya çıkmasına sebep olmuştur. Ülkemizde seramik endüstrisinin başlangıcı 1950'ler olarak kabul edilmekle birlikte 1942 yılında dönemin Cumhurbaşkanı İsmet İnönü Vedat Ar'ı Türk Seramik Endüstrisi'ni kurmak üzere görevlendirmiştir. Paris'te seramik eğitimi alan Vedat Ar, 1931 yılında diploma alarak ülkeye dönmüş ve aynı yıl bugünkü adı Mimar Sinan Güzel Sanatlar Üniversitesi olan İstanbul Devlet Güzel Sanatlar Akademisi'nin Seramik atölyesinde hoca olarak göreve başlamıştır (Ylıkoğlu, 2009: 72; Kura, 1996: 16-21).

1950 yıllarında seramik üretimi, iç ve dış mekânlar için yer-duvar karoları, sofra ve süs eşyası ve sağlık gereçlerini kapsamaktadır. Yüksek ısıya, şoklara dayanıklı refrakter, elektro porselen gibi teknik seramik alanına giren ürünler de üretilmektedir. 1950'li yılların yarısına kadar tamamı ithal edilen seramik kaplama malzemelerinin yerli üretimine ilk defa bir özel sektör kuruluşu olan Çanakkale Seramik Fabrikaları A.Ş. tarafından 1958 yılında geçilmiştir. Aynı yıllarda Bozüyük Seramik Sanayii (Sümerbank ve Emlakbank tarafından kurulan Porselen ve Çini Fabrikaları Ltd. Şti.) 1966 yılında üretime geçen kamu kuruluşu olmuştur. Ithal yasağının gereği ve inşaat sektöründeki artış, seramik malzemeye olan talebi artırmıştır (Anılanmert, 1999:67; Tansuğ, 1999: 103-112; Terwiel, 2008: 118-123).

1970'ler seramik üretimlerinde, ülkemizde bir ilk olarak Endüstri Tasarım Derneği kurma düşüncesi Dr. Eczacıbaşı ve Birgi Sanayi A.Ş.'nin kurucusu Adnan Birgi tarafından 1975 yılında ortaya atıldı. Bu dönemde seramik tasarımları adına önemli bir gelişme olmamakla birlikte o yıllarda tasarımın önemli öğelerinden biri olan renk üzerine çalışmalar yapılmıştır. illk olarak sağlık gereçlerinde okurjon, fıstık yeşil, sıklamen, pembe ve 
koyu tonlarda üretilmeye başlandı. Daha sonraları geleneksel Türk çiçek motiflerini modernize ederek, bordo ve sarı renklerin baskın olduğu çok güzel bordürler tasarladı. Bunlar çıkartma teknolojisi ile sağlık gereçlerinin üzerlerine aktarılarak büyük bir teknolojik başarı ile de 'tek pişirim' yöntemiyle bu desenlerle dekorlanmış özgün sağlık gereçleri ortaya çıktı (Ylıkoğlu, 2009: 79-88).

1980'ler dönemi seramik endüstrisinde üretimde artan kapasiteye bağlı olarak tasarım unsurunun öneminin kavranması biçiminde değerlendirilebilinir. Bu durum özellikle rekabet şartlarının gelişmesiyle ve dış satım etkinliğinin artmasıyla ortaya çıkmıştır. 1980'lerden sonra Türkiye'de hızlı ivme kazandı. Bu ivme 1990'lardan 2000'lere kadar yüksek bir hızla devam etti ve ulaştığı kapasite ile Türkiye Avrupa'da üçüncü büyük kurulu kapasiteye ulaşmış oldu. Avrupa'nın karoda ve sağlık gereçlerinde en büyük üreticisi konumuna gelmiş oldu (Vardar, 2008: 83-90).

Türkiye'nin ihraç ürünleri arasında seramik, ikinci sırayı almaktadır. Çin'den yapılan ithalat ve yurda kaçak giren porselen sofra eşyası nedeni ile sofra seramiğinde istenilen kalite ve üretim kapasitesine erişilememiştir. Ancak son yıllarda Kütahya'da bu konuda alıntılar izlenmektedir. Sağlık gereçleri ve karo üretimi en modern kuruluşlarda büyük bir kapasite ile yapılmaktadır. Sektör Alman ve italyan teknolojilerine bağımlıdır. En son araç gereç, teknoloji ve "know how" ile çalışmaktadır. Fabrikalar, hammaddelerinin büyük bir kısmını yurtiçinden sağlamaktadırlar ve tesislerini de bu kaynaklara yakın ve yakıt teminine uygun yerlerde, genellikle Ege ve Marmara bölgelerinde kurmuşlardır. Başlangıçta, özel sektör ve kamu sektörüne ait olmak üzere farklı kuruluşların yer aldığı seramik sektörü, bugün kamuya ait alanların özelleştirilmesi ile değişim geçirmiştir. Seramik endüstrisi, büyük önem taşımasa da, fırın malzemeleri, seramik makineleri gibi, yan sanayinin de oluşmasını sağlamıştır. Yeni bir yüzyıla girerken, seramik endüstrisinin önünde bulunan sorunlar, çevre standart ve yasalarına uyum, tüketimin artırılması, yeni pazarlara ulaşma ve özgün tasarımlarını üretir duruma gelmesi olarak özetlenebilir (Anılanmert, 1999: 67-73; Yılıkoğlu, 2006: 574-578).

1990'lar da seramik endüstrisi yenilikçi ve özgün tasarımlar üretmeye başladı. Bu yıllarda Türkiye'deki birçok kuruluş yurtdışına üretim ağırlıklı 
çalıştığı için, yabancı firmaların ürünlerinin kopyalanmasıyla küresel marka olunamayacağına dair tutumlarını değiştirerek tasarıma yönelmişlerdir (Yılıkoğlu, 2009: 100-108; Vardar, 2008: 82-90).

\subsection{Seramik Sektöründe 2000'li Yıllar ve Tasarım Süreci}

2000'li yıllarda özellikle seramik sektörünün çağdaşlaşma süreci kapsamında firmalar ve yatırımcılar özgün ürün geliştirme stratejisinin öneminin farkına vardılar ve bu süreçte tasarım unsuru her alanda olduğu gibi seramik endüstrisinde de büyük önem kazanmaya başladı. $\mathrm{Bu}$ dönemler de sektörde önemli bir yere sahip olan Vitra kendisi için uluslararası bir marka olma hedefini belirler ve seramik üretiminde özgün tasarım konusunu üretimlerinin odağına yerleştirir. Bu dönemde Defne Koz, Ross Lovegrove, Refik Tiniş ve Aziz Sarıyer gibi yerli ve yabancı ünlü tasarımcılarla çalışılmaya başlanır.

Ayrıca, 1996-2005 yılları arasında Eczacıbaşı Grubu Gamze Akay, İnci Mutlu, Defne Koz ve Ayşe Birsel gibi tasarımcılarla çalıştı. Dünyaca tanınan seramik sanatçısı Alev Ebüzziya Siesbye'nin Çanakkale Seramik ve Kalebodur için tasarladığı seramik karolar 2003 Tüyap Kongre ve Fuar Merkezi'nde gerçekleştirilen Unicera Banyo ve Mutfak fuarında tanıtımı yapılmıştı. Vitra, Karo için farklı teknikler kullanılarak yeniden yorumlanan İznik Çinileri, renkleri, dokuları, geometrik düzenleri ve motifleriyle Defne Koz tarafından tasarlanmıştır (Ulueren, 2005: 96-100).

1998'de Tübitak'ın Üniversite-Sanayi Ortak Araştırma Merkezleri Programı çerçevesinde kurulan SAM'ın ana faaliyetleri arasında en önemlisi seramik sektörünün ihtiyaçlarına paralel projeler oluşturmak ve bilimsel araştırmalar yaparak, çözümler üretmektir (Ulueren, 2006: 120127). Tülin Ayta'ya göre iyi bir seramik tasarımcısı; "Malzeme hakimiyeti ve üretim aşamaları konusunda temel bilgi düzeyine sahip ve yenilikçi olmalıdır. Tasarımcı alanda piyasa ekonomisi, maliyet-pazarlama ilişkileri, hedef kitlenin beğeni ve alışkanlıkları, toplumların sosyo-psikolojik davranışları ve biçimleri üzerine analiz yapabilmelidir" (Ulueren, 2007: 98-105).

Beril Anılanmert, Türkiye'de seramik endüstri gelişmelerinin seramik eğitimi üzerinde olumlu etki bıraktığına, eğitim programlarında, 
endüstrinin talepleri göz önüne alınarak yeni düzenlemelere gidildiğine dikkati çekmektedir. Disiplinlerarası çalışmaların önemsenmesi yeni teknolojilerin uygulanmasını ve endüstri ile işbirliğinin de önemini artırmaktadır (Uçarkuş, 2005: 44-49). Tülin Ayta yaklaşık 35 yılda Türk seramik sektörünün inanılmaz boyutlara ulaştığını, fakat teknolojiye dayanması kaçınılmaz olan seramik eğitiminin öz ve nitelik bakımından seramik endüstrisi ile paralel bir gelişim gösteremediğini düşünmektedir (Ulueren, 2007: 98-105).

Zehra Çobanlı'ya göre ise bugün dünyada yapılan çok sayıda konferans ve davetlerin, sanat ve eğitim etkinliklerinin ortak buluşma noktası seramik eğitiminin iyileştirilmesi, seramik sanatının geliştirilmesi, daha donanımlı bireyler yetiştirmesidir. Çobanlı "Eğitim faaliyetinde bulunan tüm seramik bölümlerinin en kısa zamanda toplanarak innavasyon için gerekli çalışmalara başlamasını" ise bir zorunluluk olarak görmektedir (Ulueren, 2007: 96-103). Üniversitelerin sanayiye eleman yetiştirmesi sektörün de gündemindedir. Sektöre kalifiye eleman yetiştirmenin şartı olarak sanayinin eğitimle iç içe olması gerektiğine inanan Türk seramik sektörü bu amaçla Özel Seramik Meslek Liseleri kurmayı düşünmektedirler (Ulueren, 2005: 46-51). Türkiye Odalar ve Borsalar Birliği tarafından kurulmuş olan Üniversite de, ülkemizde yıllardır konuşulan üniversitesanayi işbirliğini sağlamak amacındadır (Ulueren, 2007: 42-48).

\section{4. Çağdaş Seramik Sanatının Gelişimi}
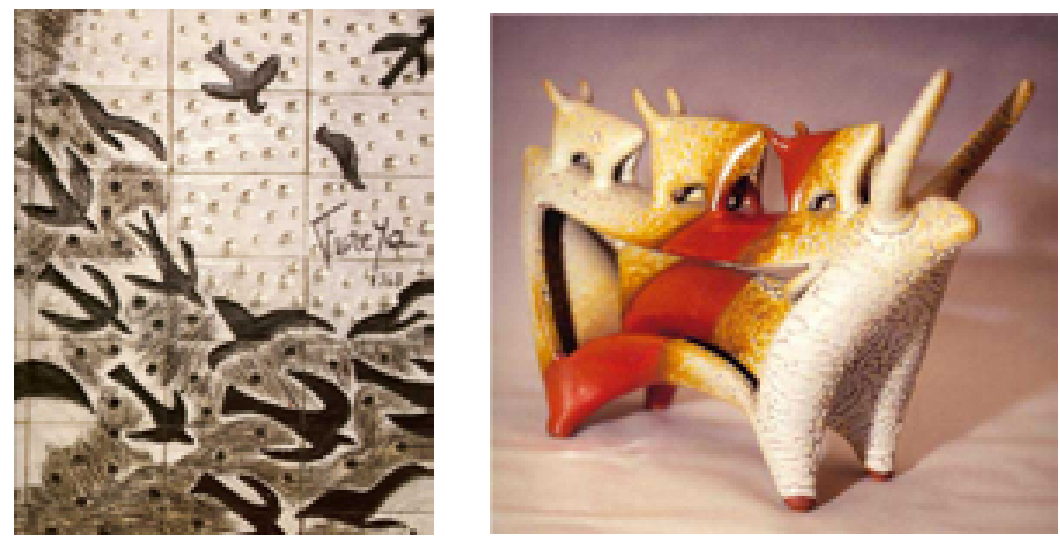

Fotoğraf 5: Füreya Koral, Kuşlar, Duvar Panosundan Ayrıntı, 1968

Fotoğraf 6: Sadi Diren, Seramik Figür, 1994 
Ülkemizde Çağdaş Seramik Sanatının gelişmesi, seramik endüstrisinin kurulması, yaygınlaşması, seramik eğitiminin örgütlenmesi ile paralellik gösterir. Cumhuriyet'in ilk yıllarında, seramik eğitimi için yurtdışına yollanan sanatçılar, bulundukları ortamın Birinci Dünya Savaşı sonrası çeşitlilik gösteren sanat akımlarının öncüleri olmuşlardır.

Paris'ten yurda davet edilen yerli sanatçlar yurda döndüklerinde seramiği geleneksel anlayıştan farklı; dekor, süsleme kavramı dışında özgün anlatım alanı olarak kullanmışlardır. Bu sırada Eczacıbaşı Seramik Fabrikası, sivil toplum örgütü olarak açmış olduğu kurslarla pek çok sanatseverin seramiğe olan ilgisinin artmasına olanak sağlamıştır. Almanya'da seramik ve heykel öğrenimi gören ve 1933'de yurda dönen Hakkı İzzet, 1952 yılında şimdiki adı Gazi Üniversitesi Gazi Eğitim Fakültesi olan Gazi Muallim Mektebi ve Terbiye Enstitüsü'ne atanmıştır. Art and Crafts Hareketi'nin uzantısı olan Almanya'daki Bauhaus Ekolü Türkiye' de 1 Kasım 1955'de Bakanlar Kurulu kararı ile 1958 yılında kurulan İstanbul Tatbiki Sanatlar Yüksek Okulu'nda vücut bulmuştur (Ağatekin, 1993: 15; Terwiel, 2008: 118-123).

1960 'ı yıllar seramik sanatında yeni isimlerin ortaya çıktığı yıllardır. Füreya Koral'ın ve İsmail Hakkı Oygar'ın oluşturdukları popülarite ve sanata daha duyarlı bir ortam olması nedeni ile birçok sanatçı seramiğe ilgi duymuş ve uygulamalar yapmıştır. Bir oluşum devresi olan bu sürede Mediha Akarsu, Nasip İyem, Saniye Fenmen ve Müfide Çalık, Tüzüm Kızılcan, Ayfer ve Sabit Karamani isimlerine rastlamaktayız. Bu sanatçılardan Nasip İyim, terra-cota figüratif formları ile tanınır. Anadolu kadını, çocuk baş ve figürlerinden oluşan çalışmalarında malzeme en yalın şekliyle kullanılmıştır (Anılanmert, 1999: 69-70). Bu yıllarda yapılarda yeni malzemelerin yer alması ile seramik uygulamaların azaldığı, sanatçıların daha kavramsal anlatımlara yöneldikleri izlenmektedir. İsmail Hakkı Oygar tarafından başlatılan çağdaş seramik sanatına duyarlılık, onun getirdiği Batı anlayışı, Füreya Koral ve Sadi Diren'in de çeşitli katkıları ile toplumda bu sanata ilgiyi artırmış ve sanatın gelişim süreci içinde dönüm noktasını oluşturmuşlardır.1960 yılından başlayarak kamu ve özel yapılarda çok sayıda özgün duvar panosu yapmış sanatçı Atilla Galatalı'nın en olgun işleri 70'lerden sonradır. Özellikle üç boyutlu işlerinde Selçuklu sanatının sağlam biçim anlayışının etkisi görülür. Sanatçı dengeli yalın anlatım üslubu, soyut biçim anlayışı ile dikkati çeker.

1970'lerde seramik sanatında daha olgun eserlerin meydana geldiğini görmekteyiz. Hamiye Çolakoğlu, Melike Abasıyanık Kurtiç, Bingül Başarır, Cevdet Altuğ, Binay Kaya, Hakkı Karayiğitoğlu, Saime Kurşunoğlu, Ünal 
Cimit, Tülin Ayta isimlerinin yanı sıra; sağlam teknikten kaynaklanan yalın ve ölçülü anlatımı ile Candeğer Furtun, hassas el yapımı kase formları ile yurtdışında yaşayan sanatçı Alev Ebuzziya, değişik şekillendirme biçimlerini birleştirerek soyut çalışmaları yapan ve anıtsal heykel gerçekleştirmiş Filiz Özgüven Galatalı isimlerine rastlanmaktadır. Ayrıca duvar panolarında süslemeci ve renkçi bir çalışma gösteren Jale Yılmabaşar, Mustafa Tunçalp, Erdinç Bakla, Feyhan Taylan Erden isimlerinin yanı sıra, tornada şekillendirilmiş heykelleri ve çeşitli teknik araştırmalara yönelmiş sanatçı kimliği ile Güngör Güner'i görmekteyiz. Beril Anılanmert soyut, ifadeci bir anlatım izleyen sanatçıdır. Zıtlıklarla oluşan, dengeli dinamik anlatımı tüm eserlerinde izlenir. Fehmi Erdoğdu, Almanya'da yaşayan ve heykelleri ile tanınan Azade Köker diğer isimlerdir. Bu süre içinde seramik sanatında büyük bir canlanma ve toplumsal ilgi izlenmektedir. Bu yıllar sanatçı ve mimar işbirliği ile yapılarda seramik ve mozaik panoların yer aldığı, sanat yarışmalarının düzenlenmesi ile yeni isim ve eserlerin ortaya çıktığı yıllardır.

Seramik sanatına duyulan bu ilgide, 1967'de Güzel Sanatlar Akademisinin önderliğinde açılan Uluslararası Çağdaş Seramik Sergisi, yine aynı kurumda 1970'te açılan Çağdaş Fransız Seramik Sergisi ve Cumhuriyet'in 50. yılında Türk sanatçılarını yurtdışında tanıtmak amacı ile düzenlenen ve Ankara, Prag, Budapeşte ve Berlin'de sergilenen 50. Yıl Seramik ve Cam Eserleri Sergisi'nin önemi büyüktür.

Avrupa seramik sanatına, çok uzun bir süre damgasın vurmuş olan Sanat ve El Sanatları Hareketi (Arts and Crafts Movement) Türk Seramik Sanatını 1970'lerin sonlarına kadar etkisi altına almıştır. Sanatçılar daha sonraları bu etkilerden sıyrılarak kavramsal sanat alanında, özgün yapıtlar ortaya koyarak çağdaş sanat içindeki yerlerini sorgulamaya başlamışlardır. Teknik engellerin aşılmasında, kavramların değişmesinde Amerikan sanatının, funk ve postmodern akımların büyük rolü olmuştur. Bugün tüm sanat dallarında olduğu gibi yaratıcılığın sınırsız ifadesi, seramik eserlerin de belirleyici niteliğidir (Anılanmert, 1999: 68-73; Yıldırım, 2011: 119-120; Özer, 2012: 60).

Türkiye'de seramik eğitimi sadece üniversitelerle sınırlı bir alan içermiyor. Seramik üretimi yapan özel atölyeler, geleneksel üretim yapan yöreler, Seramik Meslek Yüksek Okulları, Meslek Liselerinin seramik bölümleri, belediyelerce açılan seramik kursları, anaokullarında çocuklara verilen 
seramik dersleri, seramik fabrikalarında yapılan eğitim amaçlı stajlar gibi seramik eğitiminin kendi amaç ve kurallarına göre sürdürüldüğü ve neredeyse her kesime ve yaşa yönelik seramik eğitiminin verilebildiği görülmektedir. Seramik eğitiminin üniversitede verilmesinin farklılığı ise, bu eğitimi alan kişilerin birer sanatçı ve seramik eğitimcisi olarak uzmanlaşabilmeleridir (Terwiel, 2013: 31). Bu bağlamda; Çağdaş Türk Seramik Sanatı'na yön veren ve genç seramik sanatçılarına öncülük eden pek çok önemli seramik sanatçısı, akademik ve serbest çalışmalarına devam etmektedir. Bu süreç kapsamında, 1980'li yıllardan günümüze seramik alanında ciddi oranda yeni katılımlar görülmektedir.

Ayrıca Erdinç Bakla'nın İstanbul'un 100 Çini ve Seramik Sanatçısı isimli kitabında değinilen seramik sanatçılarını sıralamak ilk kuşak seramik sanatçılarından son kuşak seramik sanatçılarına dair bize genel bir bilgi verecektir. Bu sanatçılar;

“Faik Kırımlı(1935), Turgut Tuna(1945), Sıtkı Olçar(1948-2010), Faruk Şahin(1950), İbrahim Kocaoğlu(1953), Meliha Coşkun, Süreyya Oksay(1961), İsmail Yiğit(1963), İsmail Hakkı Oygar(1908-1975), Vedat $\operatorname{Ar}(1907-2001)$, Hakkı İzet(1909-1977), Füreya Koral(1910-1997), Sabit Karamani(1916-1993), Mediha Akarsu(1918-1976), Seniye Fenmen(1918-1996), Nasip İyem(1921), Hakkı Karayiğitoğlu (1926-2007), Sadi Diren(1927), Melike Abasıyanık(1930), Müfide Çalık(1930), Ayfer Karamani (1933), Hamiye Çolakoğlu(1933), Binay Kaya(1934), Ünal Cimit(1934-1993), İlgi Adalan(1936), Atilla Galatalı(1936-1994), Candeğer Furtun(1936), Erdoğan Ersen, Cevdet Altuğ, Alev Ebüzziya(1938), Bingül Başarır(1938), Filiz Özgüven Galatalı(1938-2009), Erdinç Bakla(1939), Tülin Ayta(1939), Ferhan Taylan Erder(1939), Jale Yılmabaşar(1939), Tüzüm Kızılcan(1941), Mustafa Tunçalp (1941), Güngör Güner(1941), Haluk Tezonar(1942-1994), Beril Anılanmert(1942), Türker Özdoğan(1944), Fehmi Erdoğdu(1948), Öder Ünsal(1952), Sevim Çizer(1951), TufanDağıstanlı(1952), Sadettin Aygün(1954), Sakine Çil(1956), Zerrin ErsoyBilir(1956), Cemalettin Sevim(1957), Ayla Yüce(1957), Zehra Çobanlı(1958), Gül Özturanlı(1958), Mehmet Kutlu(1959), Şeyma Bobaroğlu(1959), Candan Dizdar Terwiel(1960), Emel Şölenay(1960), Ayşegül Türedi Özen(1961), Reyhan Gürses(1961), Lerzan Özer(1962), Bilgehan Uzuner(1963), Enver Güner(1963), Halil Yoleri(1963), Soner Genç(1964), Hüseyin Özçelik(1964), Temel Köseler(1964), Yavuz Pilevneli(1964), Nalan Danabaş(1965), Aysun Çölbayır(1965), Pemra Pilevneli(1965), Oya Uzuner(1966), Pınar Genç(1966), Füsun Çövenlioğlu(1966), Sibel Sevim(1966), Kemal Uludağ(1966), Meltem Kaya(1967), Ömer Görkem(1967), Yasemin Varol(1968), Candan Güngör(1969), Fazıl Ercan(1969), Mutlu Başkaya(1969), 
İsmail Yardımcı(1969), Kaan Canduran(1969), Emre Feyzoğlu(1971), Kemal Tizgöl(1973), Kamuran Ak(1975), Burcu Öztürk Karabey(1975), Hasan Şahbaz(1975), Hasan Başkırkan(1975), Feyza Çakır Özgündoğdu(1976), Deniz Onur Erman(1978), Egemen Işık Aslan(1978), OlguSümengen(1978), Ezgi Hakan(1979), Nizam Orçun Önal(1979), Pınar Baklan Önal(1986)" (Bakla, 2010:30-302)"

\section{Sonuç}

Sanat, toplum ve kültürün birbiri içinde aşkınlaşarak eriyen hatta zaman içinde evrimleşen bir biçim olarak karşımıza çıkmaktadır. Toplumsal yaşam döngüsünün kültürel yapı üzerindeki etkilerinin veya etkilenmelerinin en önemli paradigmalarından birisi de tartışmasız olarak Endüstri Devrimi'dir. $\mathrm{Bu}$ tarihsel süreçte dünyanın her yerinde bilim, mühendislik ve sanat alanlarında endüstrileşme faaliyetleri ile hız kazanmıştır. Bu durum sadece seramik sanatının gelişiminin ötesinde seramik sanatının, eğitiminin ve endüstrisinin gelişmesinde de çok önemli rol oynar.

Batılı anlamda bir eğitim almış olan öğrenciler, orada hâkim olan sanat anlayışlarını Türk seramik eğitimine taşıyarak Çağdaş Türk Seramik Sanatı'nı ulusal niteliklerinden çıkararak uluslararası boyutlara taşınmasında öncülük etmişlerdir. Bu anlamda unutulmamalıdır ki, çağımızın sanat pratikleri ve dinamikleri açısından bakıldığı zaman Çağdaş Türk Seramiğinin geliştirilmesi sürecinde seramik sektöründeki iş adamları ve yatırımcılara, serbest sanatçılara, akademisyen sanatçılara ve alan öğrencilerine büyük sorumluluklar düşmektedir.

Çağdaş Türk Seramik Sanatı Anadolu'nun zengin kültürünün de etkisiyle temellenen ve özgün üretimleriyle fark yaratan günümüz seramik sanatını şekillendirilmeye devam etmektedir/edecektir. Ayrıca artistik ve endüstriyel alanlarda büyük ivme kazanmış olan Çağdaş Türk Seramik Sanatı'nın gelişim süreci; donanımlı seramik atölyelerinin kurulması, sanayinin eğitim ve üretim sektörünü desteklemesi, önlisans-lisans ve lisansüstü alanlarda akademik eğitim kalitesinin artırılması, ulusal/uluslararası bianel, trianel, çalıştay, yarışma ve karma sergilerin niceliksel ve niteliksel olarak artması ve bireysel çabalar sayesinde hızla devam edecektir. 


\section{Kaynakça}

Ağatekin, M. (1993). Cumhuriyet Sonrası Çă̆daş Türk Seramik Sanatının Gelişimi ve Anlatım Dili Yönünden Değerlendirilmesi, Yüksek Lisans Tezi, Anadolu Üniversitesi Güzel Sanatlar Fakültesi, Eskişehir.

Aliçavuşoğlu, E. (2009). Bauhaus Geleneği ve Günümüz Sanatına Yansımaları., A. Artun ve E. Aliçavuşoğlu. (Derleyen). Bauhaus: Modernleşmenin Tasarımı. İstanbul. Iletişim Yayınları, s.23.

Altıparmak, A. (2002). Türkiye’de Devletçilik Döneminde Özel Sektör Sanayiin Gelişimi, Erciyes Üniversitesi Sosyal Bilimler Enstitüsü Dergisi, Sayı: 13,35-59.

Anılanmert, B. (1999). Cumhuriyetin Renkleri, Biçimleri, Istanbul: Tarih Vakfı Yayınları.

Bakla, E. (2010). İstanbul'un 100 Çini ve Seramik Sanatçısı, İstanbul: İstanbul Büyükşehir Belediyesi Yayınları.

Bektaş, D. (1992). Çă̆daş Grafik Tasarımının Gelişimi, İstanbul:Yapı Kredi Yayınları.

Bosworth, J. (2006). Ceramicswith Mixed Media, Philadelphia: A \& C Black London.

Çil, S. (2006). Geleneksel Çömlek Formlarında Picasso Yorumu.VI. Uluslararası Katılımlı Seramik Kongresinde sunuldu, Türk Seramik Derneği Yayınları, No:23.

Erzen, J. N. (I99I). Çă̆daş Düşünce ve Sanat.,I. Duben ve D. Şengel (Editörler). Modernizm Sonrası Sanat, İstanbul, Plastik Sanatlar Derneği Yayınları, No:I.

Gençaydın, Z.(1997). Giriş Bölümü, Hacettepe Üniversitesi Güzel Sanatlar Fakültesi Yayınları 16, Ankara.

Howard, J. (1996). Art Nouveau: International andNationalStyles in Europe, UK: Manchester UniversityPress.

Kura, H. (1989). Endüstriyel Seramik Tasarımında Biçim ve Üretim Yöntemleri, Yayınlanmamış Sanatta Yeterlik Eser Çalışması Raporu, Mimar Sinan Üniversitesi Sosyal Bilimler Enstitüsü, İstanbul.

Kura, H. (1996). Bir Sanatçı: Vedat Ar, Seramik Dünyası, Sayı: I 7, I6-2I. 
Küçükerman, Ö. (1987). Dünya Saraylarının Prestij Teknolojisi ve Porselen Sanatı ve Yıldız Çini Fabrikası, Ankara: Sümerbank Genel Müdürlügü̈ Yayınları.

Özen Türedi, A. (1993). Ateşin Toprağa Hükmettiği Sanat, Anadolu Sanat Dergisi, Sayı:I, 157-163.

Özer, L. (20I2). Türk Seramik Sanatında Eğilimler, Türk Standartları Enstitüsü Dergisi, Sayı 598,56-6I.

Özturanlı, G. (1989). Geleneksel Tasarım ile Çağdaş Tasarım İlişkilerinin Değerlendirilmesi, Yayınlanmamış Sanatta Yeterlik Çalışması, Mimar Sinan Üniversitesi, Sosyal Bilimler Enstitüsü, İstanbul.

Özturanlı, G. (1998). Modern Türk Seramik Sanatına Bir Bakış, Türkiye'de Sanat Plastik Sanatlar Dergisi, Sayı:33,3I-33.

Seramik Tanıtım Komitesi. (2003). Türkiye'de Seramik: Toprakla Ateşin Öyküsü, İstanbul: Grup 7 iletişim Hizmetleri.

Soner, Ş. T. (2007). Endüstrileşme Sürecinde Tasarım ve William Morris, Yayınlanmamış Yüksek Lisans Tezi, Akdeniz Üniversitesi, Sosyal Bilimler Enstitüsü, Antalya.

Sönmez, N. (2002). Nesne, Sanatçı ve Seramik Sanatı Illişkisi, Anadolu Sanat Dergisi, Sayı: 13, I75-183.

Tansuğ, S. (1988). Candeğer Furtun ve Çağdaş Seramiğin Sorunları, Argos Yeryüzü Kültür Dergisi, No:3, 93-105.

Tansuğ, S. ( 1999). Çağdaş Türk Sanatı, İstanbul:Remzi Kitabevi.

Terwiel Dizdar, C. (2008). Türkiye'de Seramik Sanatının Kurumsallaşması, Seramik Federasyonu Dergisi, No:24, I /8-I 23.

Terwiel Dizdar, C. (20/3). Candan Dizdar Terwiel Ile Seramik Sanatı Üzerine, Seramik Federasyonu Dergisi, Sayı 31.

Tunalı, i. (1997). Sanayi, Insan ve Sanat, Hacettepe Üniversitesi Güzel Sanatlar Fakültesi Yayınları, Sayı: 16. 
Turan, G. (2009). Türkiye'de Erken Cumhuriyet Dönemi Zanaat ve Endüstri Üretiminde Tasarım, Yayınlanmamış Doktora Tezi, İstanbul Teknik Üniversitesi, Sosyal Bilimler Enstitüsü, İstanbul.

Ulueren, Ş.D. (2005). Defne Koz ile Röportaj, Seramik Türkiye, Sayı:9, 96-I00.

Ulueren, Ş.D. (2006). Anadolu Üniversitesi Öğretim Üyesi ve Seramik Araştırma Merkezi (SAM) Müdürü Prof. Ferhat Kara ile Röportaj, Seramik Türkiye, Sayı: 17, 98-104.

Ulueren, Ş.D. (2007). Tülin Ayta ile Röportaj, Seramik Türkiye, Sayı:19, 98-105.

Ulueren, Ş.D. (2008). Mehmet Yavaş ile Röportaj, Seramik Türkiye, Sayı:24, 98-I03.

Vardar, N. (2008). Türk Markaları Ansiklopedisi II, İstanbul: Reklamcılık Vakfı Yayınları.

Yağcı Başkaya, M. (2009). Sanatsal Formlarda Seramik ve Karışık Teknik Birlikteliği, Sanatta Yeterlilik Eseri Çalışma Raporu,Hacettepe Üniversitesi Sosyal Bilimler Enstitüsü Ankara.

Yıldırım, L. (20II). Sanat- Zanaat Buluşması ve WienerWerkstätte Tekstilleri, Gazi Üniversitesi Güzel Sanatlar Fakültesi Sanat ve Tasarım Dergisi, Sayı 8, I05- 122.

Yılıkoğlu, H. (2006). Türk Seramik Endüstrisinde Tasarım, Türk Seramik Derneği Yayınları, No:23, 22I-230.

Yılıkoğlu, H. (2009). Türk Seramik Endüstrisinde Ürün Biçimlerindeki Gelişimin Değerlendirilmesi, Yayınlanmamış Sanatta Yeterlilik Tezi, Mimar Sinan Üniversitesi Sosyal Bilimler Enstitüsü, İstanbul.

Yorgancıoğlu, D. (2009). 20. Yüzyııın İlk Yarısında Bauhaus Fikirlerinin Amerika Kıtasındaki Yolculuğu, İstanbul: İletişim Yayınları.

\section{Görsel Kaynakları}

(Erişim Tarihi: 02.12.2013)

Fotoğraf 1: http://makeitpart.blogspot.com.tr

Fotoğraf 2:http://www.martygrossfilms.com/films/leach/leach

Fotoğraf 3: http://fvsarts.pbworks.com/w/page/Picasso

Fotoğraf 4: https://www.google.com.tr/search?q=miro\&espv-joan-miro

Fotoğraf 5: http://astrolozibyzizi.blogspot.com.tr/2013/12/fureya-koral

Fotoğraf 6: http://kadifeklos.blogspot.com.tr/2013/07/normal-sadi-diren 
